\title{
Benarkah anak prasekolah sudah mampu mengambil perspektif dalam perilaku prososial?
}

\author{
Putri Arlanda Permatasari*, Hendriati Agustiani, \& Amir Sjarif Bachtiar \\ Fakultas Psikologi, Universitas Padjajaran, Bandung, Jawa Barat
}

\begin{abstract}
Abstrak
Berdasarkan penelitian terdahulu, diasumsikan bahwa anak prasekolah sudah menunjukkan perilaku prososial. Namun demikian, masih ada inkonsistensi antar perspektif teoretis. Penelitian ini bertujuan untuk mengeksplorasi apakah pengambilan perspektif dan peran pengambilan perspektif dalam melakukan perilaku prososial pada anak prasekolah memang sudah berkembang sebagaimana asumsi teori sebelumnya. Partisipan penelitian merupakan 25 anak prasekolah yang berusia 5-6 tahun. Hasil penelitian menunjukkan bahwa dari ketiga jenis pengambilan perspektif, yaitu pengambilan perspektif perseptual, kognitif, dan afektif, kondisi pengambilan perspektif afektif belum berkembang optimal pada mayoritas anakanak. Anak-anak masih kesulitan untuk memahami emosi yang dimunculkan orang lain dalam konteksnya, khususnya dalam konteks ketika ada orang lain yang sedang kesulitan. Pada pengambilan perspektif kognitif, anak-anak sudah bisa memahami pemikiran, intensi, maupun motif yang dipikirkan oleh orang lain, tetapi hanya pada situasi dimana sinyal dari lingkungannya sederhana. Perbedaan pemahaman anak terhadap situasi yang dihadapi orang lain mengakibatkan perbedaan respon perilaku prososial yang dikemukakan anak. Untuk kemampuan pengambilan perspektif perseptual yang dimiliki anak, anak-anak sudah dapat mengalihkan sudut pandang visualnya dari dirinya menjadi ke sudut pandang visual orang lain. Temuan dalam penelitian ini dapat digunakan sebagai salah satu dasar pengembangan program intervensi untuk meningkatkan keterampilan pengambilan perspektif dalam berperilaku prososial pada anak.
\end{abstract}

Kata kunci: pengambilan perspektif, perilaku prososial, anak prasekolah

\begin{abstract}
Previous studies suggested that preschoolers have already behaved prosocially. However, there is a possibility that such insight cannot be generalized since there is a conflicting assumption between different theoretical perspectives. The research aimed to explore whether preschoolers' perspective-taking in the context of prosocial behavior had developed. Our participants were 25 preschoolers who were 5-6 years old. The result showed that from the three types of perspective-taking, which were perceptual, cognitive, and affective perspective-taking, affective perspective-taking was undeveloped optimally among the majority of pre-schoolers. They had difficulty when identified others' emotions in the context, especially in prosocial situations. For cognitive perspective-taking, preschoolers understood other people's thoughts, intentions, and motives, but only when the environmental cues were simple. When the situation was more complex, their efforts to understand other people's thoughts, intentions, or motives resulting in different understanding about the situations. Preschoolers' ability to do perceptual perspective-taking had developed. They could shift their perceptual perspective-taking from themselves to other perceptual perspective-taking. The results can be used as a reference for developing intervention programs to improve perspective-taking skills in contexts of prosocial behavior in preschool children.
\end{abstract}

Keywords: perspective-taking, prosocial behavior, preschoolers 


\section{Pendahuluan}

Perilaku prososial nampaknya perilaku yang perlu ditanamkan sejak anak-anak karena memiliki peran penting dalam perkembangan moral anak di masa depan (Eisenberg \& Sadovsky, 2004). Perilaku prososial merupakan perilaku sukarela yang dimaksudkan untuk meringankan kesulitan atau menguntungkan individu atau sekelompok individu lain (Eisenberg \& Mussen, 1989). Dalam perkembangannya, proses pengambilan perspektif merupakan salah satu proses kognitif yang penting sebagai determinan perilaku prososial. Pengambilan perspektif merupakan proses kognitif yang muncul sebelum perilaku prososial dilakukan oleh anak, sehingga bagaimana proses pengambilan perspektif yang terjadi akan mempengaruhi bagaimana performa perilaku prososialnya. Anak dengan kemampuan pengambilan perspektif yang lebih tinggi, secara umum, akan menunjukkan perilaku prososial yang lebih banyak (Eisenberg, Spinrad, \& KnafoFoam, 2015).

Berbagai studi telah dilakukan untuk melihat respon perilaku prososial yang dimunculkan oleh anak (Himmah \& Rahmanawati, 2013; Matondang, 2016; Susanti, Siswati, \& Astuti, 2013). Beberapa penelitian menghasilkan temuan bahwa pengambilan perspektif berperan dalam memunculkan perilaku prososial (Adni, 2017; Paulus, 2014; Sierksma, Thijs, Verkuyten, \& Komter, 2014; Theresia, 2013). Ini konsisten dengan asumsi bahwa perilaku prososial penting secara evolusioner, bahkan sejak masa bayi (Brownell, 2013). Sementara studi-studi lain telah menganalisa secara mendalam mengenai hubungan mengenai pengambilan perspektif (Carlo, Knight, McGinley, Goodvin, \& Roesch, 2010; Hinnant \& O’Brien, 2007; Imuta, Henry, Slaughter, Selcuk, \& Ruffman, 2016). Pada studi-studi itu, dibahas mengenai hubungan pengambilan perspektif kognitif dan afektif terhadap pro-sosial, tetapi tidak mengikutsertakan pengambilan perspektif perseptual. Konsisten dengan studi-studi ini, diasumsikan bahwa kapasitas pengambilan perspektif meningkat drastis dari usia 2-3 tahun hingga usia remaja dan termasuk pemahaman akan pikiran dan perasaan orang lain (Eisenberg, 1986). Anak usia prasekolah, yang berusia 4-5 tahun, berada pada periode kritis perkembangan kemampuan untuk mengatribusikan keadaan mental individu dengan asumsi akan sudut pandang orang lain (Cigala, Mori, \& Fangareggi, 2014).

Akan tetapi, asumsi teori Piaget mengemukakan bahwa perkembangan kognitif untuk pengambilan perspektif anak baru muncul pada tahap operasional konkrit-yaitu setidaknya anak harus berusia 7 tahun (Piaget, 1965; Kohler,
2008). Dengan kata lain, perkembangan pengambilan perspektif sosial, empati, dan perilaku prososial mungkin belum sepenuhnya berkembang pada anak-anak usia prasekolah. Riset neurosains pada tahun 2018 juga menemukan bahwa tidak semua faset dari empati bisa ditemukan pada anak prasekolah (Decety, Meidenbauer, \& Cowell, 2018). Lebih penting lagi, meta analisis pada tahun 2016 juga menyimpulkan bahwa pengambilan perspektif untuk perilaku prososial juga baru muncul pada usia 6 tahun ke atas, dan bukan di bawah itu (Imuta, dkk., 2016). Data aktual dari Dinas Pendidikan Jatinangor bagian Taman Kanak-Kanak menunjukkan bahwa masih banyak anak yang belum memunculkan perilaku saling tolong menolong dengan temannya. Salah seorang Kepala Sekolah Taman Kanak Kanak di Jatinangor, Jawa Barat, mengemukakan hasil observasinya bahwa anak-anak di sekolahnya masih banyak yang belum menunjukkan perilaku prososial saat berinteraksi dengan teman maupun gurunya.

Dalam penelitian ini, peneliti mendalami proses pengambilan perspektif dalam konteks berperilaku prososial pada anak-anak, dengan berfokus pada proses pengambilan perspektif perseptual, kognitif, dan afektif (Eisenberg, 1986). Ketiga tipe pengambilan perspektif ini saling memengaruhi satu dengan lainnya dalam proses memunculkan perilaku prososial. Analisis pada tiga aspek ini juga penting untuk mengeksplorasi faset apa yang sebetulnya sudah berkembang atau belum berkembang pada anak. Pengambilan perspektif perseptual didefinisikan sebagai kemampuan untuk memahami secara harfiah perspektif visual orang lain; pengambilan perspektif kognitif didefinisikan sebagai kemampuan untuk memprediksi dan memahami pikiran, motif, intensi, dan perilaku orang lain; dan pengambilan perspektif afektif didefinisikan sebagai kemampuan untuk menyimpulkan perasaan dan reaksi emosi orang lain (Eisenberg, 1986).

Hasil penelitian ini diharapkan dapat memperkaya pengetahuan terhadap pengembangan ilmu psikologi sosial dalam kajiannya mengenai pengambilan perspektif, yaitu pengambilan perspektif perseptual, kognitif, dan afektif, dalam perilaku prososial pada anak prasekolah. Secara praktis, hasil penelitian ini dapat menjadi dasar pengembangan intervensi terkait peningkatan pengambilan perspektif pada anak prasekolah sehingga anak-anak dapat lebih berperilaku prososial.

\section{Metode Penelitian}

\section{Partisipan}


Teknik pengambilan sampel yang digunakan adalah purposeful sampling, yaitu pemilihan partisipan dalam penelitian atau pemilihan lokasi dilakukannya penelitian, dilakukan secara sengaja oleh peneliti untuk mempelajari atau memahami fenomena yang terjadi (Creswell, 2014). Strategi sampling yang digunakan adalah homogeneous sampling, di mana peneliti secara sengaja memilih sampel individu atau lokasi berdasarkan keanggotaan dalam sebuah sub kelompok yang memiliki karakteristik yang jelas (Creswell, 2014). Taman Kanak-Kanak yang dijadikan lokasi penelitian terletak di Jatinangor, Sumedang, Jawa Barat. Pemilihan Taman Kanak-Kanak tersebut dilakukan karena siswa-siswanya memiliki latar belakang keluarga dengan status ekonomi sosial yang serupa yaitu menengah ke atas, pendidikan di Taman Kanak-Kanak tidak berdasarkan pada salah satu agama tertentu, dan keterbukaan pihak sekolah terhadap penelitian yang dilaksanakan.

Mengingat bahwa partisipan merupakan anak-anak, beberapa kajian kode etik dilakukan oleh peneliti. Sebelum pengambilan data, peneliti melakukan diskusi mengenai proses penelitian dengan Kepala Sekolah dan guru untuk memastikan bahwa tidak ada dampak yang dapat menyakiti anak-anak. Setelah itu, peneliti menjelaskan kepada orang tua atau wali mengenai tujuan, prosedur, waktu, dan dampak dari penelitian yang akan diikuti anak. Jika mereka bersedia, maka diminta kesediaannya secara tertulis untuk mengizinkan anaknya mengikuti penelitian. Orang tua juga diperkenankan melihat proses penelitan yang berlangsung dari luar ruangan melalui jendela.

\section{Desain}

Penelitian ini menggunakan pendekatan penelitian kualitatif, yaitu sebuah pendekatan untuk menyelidiki dan memahami makna individu atau kelompok yang dianggap sebagai masalah manusia atau sosial (Creswell \& Creswell, 2018). Pendekatan kualitatif dipilih dengan tujuan mendapatkan gambaran mengenai pengambilan perspektif dalam perilaku prososial pada anak prasekolah secara lebih mendalam dan komprehensif.

Alat ukur asesmen penelitian dikembangkan dari teori pengambilan perspektif, yaitu perseptual, afektif, dan kognitif (Eisenberg, 1986). Untuk mengukur pengambilan perspektif perseptual digunakan alat peraga berupa miniatur hutan. Alat ukur pengambilan perspektif perseptual dibuat dengan memodifikasi alat asesmen yang di- buat oleh Piaget (Borke, 1975) untuk mengukur pengambilan perspektif perseptual. Sedangkan untuk mengukur pengambilan perspektif kognitif dan afektif, peneliti menggunakan empat kartu bergambar dan tiga video animasi. Alat ukur pengambilan perspektif afektif dan kognitif dibuat dengan menyesuaikan konteks situasi yang dapat memunculkan tiga respon prososial (Eisenberg, Cameron, \& Tryon, 1984). Kartu bergambar yang digunakan dapat dilihat pada Gambar 1 .

\section{Prosedur}

Terdapat beberapa langkah asesmen yang dilakukan dalam penelitian. Pertama, asesmen pengambilan perspektif perseptual. Partisipan diperlihatkan seluruh sisi alat peraga dan diminta menyebutkan objek yang dilihat di hadapannya. Selanjutnya, partisipan diminta menyebutkan objek yang dilihat orang lain yang berada di seberangnya.

Kedua, asesmen pengambilan perspektif kognitif dan afektif. Partisipan diperlihatkan kartu bergambar satu per satu. Kemudian, mereka diminta untuk menjelaskan situasi yang dihadapi tokoh, termasuk pemikiran, intensi, atau motifnya, dan emosi yang dimunculkan tokoh. Setelah selesai dengan kartu bergambar, partisipan diminta menonton tiga video animasi melalui laptop yang telah disediakan. Kemudian partisipan diminta lagi untuk menjelaskan situasi yang dihadapi tokoh, termasuk pemikiran, intensi, atau motifnya, dan emosi yang dimunculkan oleh tokoh.

Proses asesmen dilakukan secara satu per satu antara peneliti dengan partisipan. Namun, pada beberapa partisipan mereka melakukan asesmen berdua dengan partisipan lain. Peneliti belum pernah berinteraksi sebelumnya dengan siswa di sekolah yang terlibat dalam penelitian. Maka dari itu, peneliti meminta bantuan guru untuk memilihkan siswa yang akan berpartisipasi dalam penelitian. Proses asesmen dilakukan oleh peneliti sendiri dengan latar belakang sebagai mahasiswa Magister Profesi Psikologi majoring Psikologi Sosial, Universitas Padjadjaran.

Dalam berlangsungnya proses asesmen, terdapat situasi eksternal tidak terduga, yaitu gangguan dari anak-anak yang sedang tidak berpartisipasi dalam asesmen dan situasi ruangan asesmen yang kurang memadai, yang menyebabkan terdapat beberapa data asesmen yang tidak lengkap. 
Gambar 1.

Kartu bergambar pengambilan perspektif kognitif dan afektif

1.

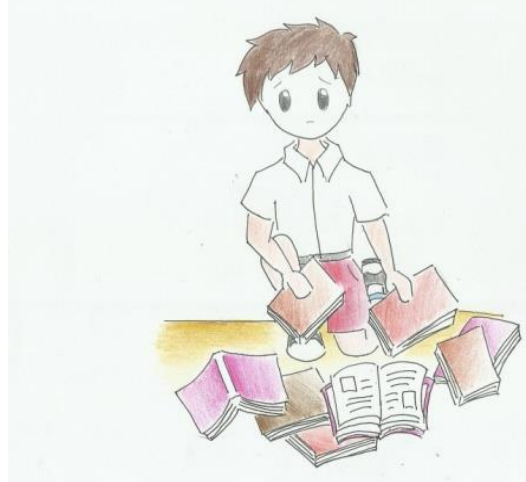

2.

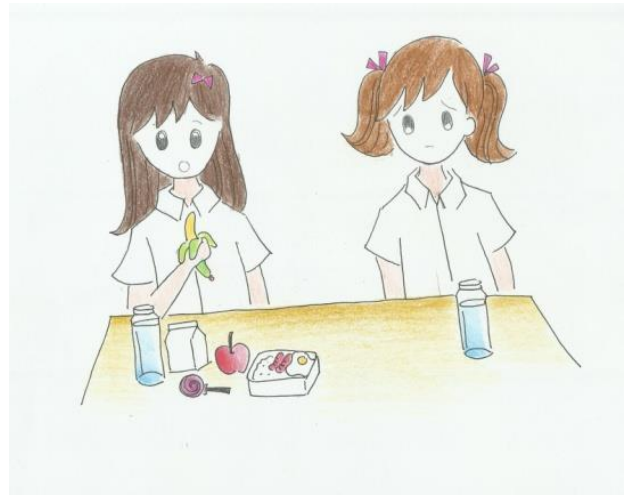

3.
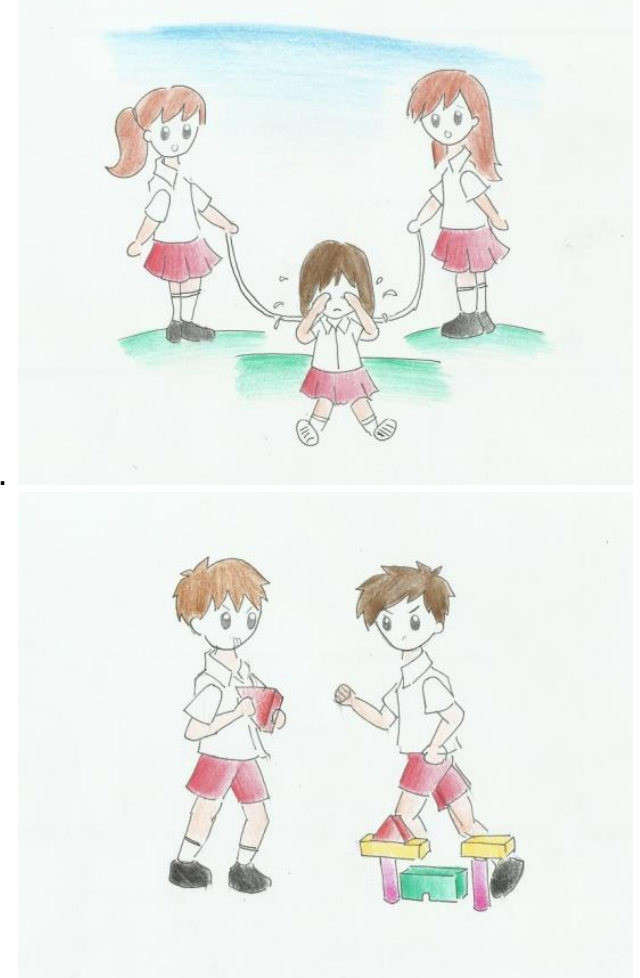

4.

baan pertama. Setelah gagal pada percobaan pertama, partisipan diberikan kesempatan untuk melihat seluruh sisi miniatur dan diajukan pertanyaan yang sama. Hasilnya adalah mereka dapat menjawab dengan benar objek yang berada di seberangnya pada percobaan kedua.

Partisipan yang perkembangan pengambilan perspektif perseptualnya sudah berkembang optimal, berarti partisipan tersebut dapat menyebutkan objek yang berada di posisi seberangnya secara tepat pada percobaan pertama. Dari respons yang diberikan, terdapat perbedaan nama objek yang disebutkan. Meskipun demikian, partispan dapat menyebutkan nama objek secara tepat ketika ditanyakan mengenai objek yang berada di seberangnya. Contoh respons yang muncul sebagai berikut.

“(posisi $0^{0}$ ) singa dan zebra (diputar 180", anak tidak dapat melihat objek di seberangnya) singa dan zebra" (Subjek 1)"

“(posisi $0^{0}$ ) kuda dan harimau. (diputar 180", anak tidak dapat melihat objek di seberang nya) kuda dan harimau" (Subjek 18)

Asesmen pengambilan perspektif kognitif dilakukan untuk mengetahui kemampuan anak dalam memahami situasi orang lain terutama da- 
lam situasi dimana orang lain memerlukan respon prososial. Asesmen juga dilakukan untuk mengetahui respon prososial yang dimunculkan anak saat melihat situasi orang lain. Data asesmen pengambilan perspektif kognitif dapat dilihat pada Tabel 1 (Lampiran). Asesmen pengambilan perspektif afektif dilakukan untuk mengetahui kemampuan anak dalam menyimpulkan perasaan dan reaksi emosi orang lain. Data asesmen pengambilan perspektif dapat dilihat pada Tabel 2 (Lampiran).

\section{Diskusi}

"Perspective taking is used to refer to the ability to engage in any of these processes when they result in knowledge about others' internal states." (Eisenberg, Spinrad, \& Knafo-Foam, 2015, hal. 635)

[Pengambilan perspektif merupakan kemampuan untuk terlibat dalam salah satu proses yang menghasilkan pengetahuan mengenai kondisi internal orang lain].

Dari kutipan di atas, kondisi internal orang lain yang dimaksud termasuk reaksi emosi, pikiran, perspektif, motif, dan intensi yang dimiliki orang lain (Eisenberg \& Mussen, 1989). Informasi mengenai kondisi internal orang lain tersebut didapatkan anak dengan mengimajinasikan dirinya di posisi orang lain, atau menggunakan 'teori' yang telah dimilikinya untuk menyimpulkan kondisi internal orang lain (Eisenberg, Fabes, \& Spinrad, 2006). Terdapat tiga proses kognitif yang terlibat untuk menghasilkan pengetahuan mengenai kondisi internal orang lain, yaitu pengambilan perspektif perseptual, pengambilan perspektif kognitif, dan pengambilan perspektif afektif (Eisenberg \& Mussen, 1989).

Berdasarkan hasil asesmen pengambilan perspektif perseptual, anak-anak sudah mampu menyebutkan objek yang dilihat dari sudut pandang orang lain yang berada di seberangnya. Kondisi tersebut menunjukkan bahwa anak-anak usia 5-6 tahun sudah dapat melakukan 'decenter', di mana mereka dapat melihat lebih dari satu sudut pandang pada saat yang bersamaan. Mereka telah dapat memosisikan dirinya dari posisi orang lain dan melihat, secara harfiah, apa yang dilihat orang tersebut.

Kondisi ini berbeda dengan teori populer yang dikemukakan oleh Piaget (Eisenberg \& Mussen, 1989) di mana anak-anak di bawah usia 7 tahun belum memiliki kematangan kognitif untuk melihat dari sudut pandang orang lain. Borke (1975) melakukan penelitian ulang mengenai pengambilan perspektif perseptual yang dilakukan oleh Piaget, menyatakan bahwa anak usia 3-4 tahun sudah mampu memahami perspektif orang lain. Borke mengemukakan bahwa tugas yang di- berikan pada penelitan Piaget untuk mengukur egosentrisme terlalu sulit bagi anak kecil, yang mengakibatkan anak-anak di bawah usia 7 tahun gagal menyelesaikan tugas yang diberikan dengan baik. Minimal pada saat anak berusia 2 tahun, mereka tidak menunjukkan egosentrismenya, yang maksudnya, tidak mengetahui bahwa orang lain melihat tampilan yang berbeda (Newcombe, 1989).

Kegagalan anak dalam melakukan pengambilan perspektif perseptual dikarenakan mereka tidak dapat menyebutkan objek di hadapan orang lain yang berada di seberangnya pada percobaan pertama. Namun pada kesempatan kedua, mereka dapat menyebutkan objek di hadapan orang lain yang berada di seberangnya. Berdasarkan data observasi ketika anak menjalani proses asesmen, mereka menunjukkan gestur menggumamkan 'hhmm' sambil menggerakkan bola mata melihat ke atas dan mengerutkan dahinya, yang disimpulkan sebagai proses sedang berpikir. Tidak ada anak yang menjawab pertanyaan mengenai objek yang dilihat oleh orang di seberangnya dengan objek yang berada tepat di hadapannya. Ketika asesmen diulang kembali dari awal setelah kegagalan pertama, anak dapat dengan cepat menyebutkan objek yang dilihat oleh orang lain di seberangnya. Kegagalan anak dalam menyebutkan objek di seberangnya pada percobaan pertama dikarenakan belum matangnya kemampuan kognitif anak, terutama kapasitas memori anak. Kecepatan anak dalam menyebutkan pengulangan stimulus yang masuk merupakan prediktor kemampuan rentang memori anak (Santrock, 2011). Pengulangan pemberian informasi menguatkan memori jangka pendek anak, sehingga anak dapat menyebutkan objek yang berada di hadapan orang di seberangnya pada percobaan kedua.

Hasil asesmen pengambilan perspektif kognitif menunjukkan bahwa ketika sinyal yang muncul dari lingkungan berbentuk sederhana, konkrit, dan jelas, anak lebih mudah menyimpulkan apa yang dipikirkan oleh orang lain. Anakanak secara seragam mengemukakan pemahaman yang sama akan perilaku yang dimunculkan orang lain pada situasi yang sederhana dan konkrit. Perbedaan pemahaman akan perilaku yang dimunculkan orang lain dapat terjadi ketika terdapat perbedaan penangkapan sinyal yang muncul dari lingkungan. Ketika sinyal dari lingkungan lebih sulit, seperti kompleksitas intonasi suara tokoh, konten percakapan antar tokoh, konteks situasi yang berlangsung, dan ekspresi emosi, anak lebih kesulitan untuk memahami apa yang dipikirkan maupun intensi dari perilaku orang lain. Konteks informasi yang muncul dari lingkungan seringkali lebih penting dari konten sinyal itu sendiri, sehingga sinyal yang sama dari lingkungan dapat memunculkan persepsi yang berbeda tergantung 
kondisi personal dan lingkungan tersebut (Ristic \& Enns, 2015). Perbedaan pemahaman akan situasi yang muncul juga dipengaruhi perbedaan infomasi yang dimiliki anak sebelumnya melalui proses sosiali-sasi dari lingkungannya. Input, menerjemahan in-formasi yang masuk, dan coding informasi dari sensori individu dalam proses persepsi merupa-kan proses yang penting untuk menghasilkan pemikiran dan tindakan tertentu (Bornstein, Arterberry, \& Mash, 2011). Sosialisasi mengenai situasi sehari-hari yang berpotensi memunculkan respons prososial dan nilai moral yang perlu dipa-hami oleh anak didapatkan melalui pendidikan di rumah maupun di sekolah. Meskipun terdapat kontribusi genetik pada perilaku prososial anak, sosialisasi juga memiliki peran yang penting dalam mengembangkan perilaku prososial (Eisenberg, Spinrad, \& Knafo-Foam, 2015). Pengaruh media pada saat ini memiliki dampak yang besar pada anak, sehingga pengawasan orang tua terhadap pemaparan media pada anak perlu dilakukan sebagai usaha mengontrol meningkatkan perilaku prososial pada anak (Ostrow, Gentile, \& Crick, 2006).

Berdasarkan hasil asesmen pengambilan perspektif afektif, anak-anak kesulitan menjawab pertanyaan mengenai perasaan orang lain secara lisan. Mereka akan diam atau menjawab tidak tahu ketika ditanyakan mengenai emosi yang dimunculkan. Namun, mereka dapat lebih mudah menjawab pertanyaan mengenai emosi yang dimunculkan ketika menggunakan gambar ekspresi wajah. Berdasarkan tahap perkembangan kognitif Piaget (Kohler, 2008), anak yang memilih menggunakan gambar ekspresi wajah untuk mendeskripsikan emosi menunjukkan bahwa anak tersebut masih berada pada sub-tahap pemikiran simbolis dalam tahap perkembangan kognitif preoperasional, karena anak menggunakan simbol daripada bahasa untuk mengemukakan pikirannya. Padahal, seharusnya anak prasekolah yang usia 5-6 tahun sudah berada di sub-tahap setelahnya, yaitu pemikiran intuitif, dimana anak sudah mahir berbahasa sehingga mereka dapat mengemukakan pemikirannya melalui bahasa (Kohler, 2008). Pemilihan kartu ekspresi wajah oleh anak karena kesamaan bentuk mulut dan matanya antara stimulus kartu bergambar maupun animasi yang diberikan dengan kartu ekspresi wajah, menguatkan pernyataan bahwa mereka masih berada pada sub-tahap pemikiran simbolis karena mereka melakukan imitasi dari bentuk muka pada stimulus kartu bergambar atau animasi ke bentuk muka di kartu ekpresi wajah. Piaget (Kohler, 2008) mengemukakan situasi tersebut sebagai permainan simbolis.

Kondisi yang muncul pada anak-anak, di mana mereka kesulitan dalam mengidentifikasi emosi yang dimunculkan orang lain dalam konteks tertentu, bertentangan dengan perkembangan emosi anak. Santrock (2011) mengatakan bahwa kebanyakan anak usia 5 tahun dapat secara akurat mengidentifikasikan emosi yang dihasilkan dalam situasi yang sulit dan mereka dapat memahami bahwa situasi yang sama dapat menyebabkan perbedaan perasaan yang berbedabeda pada setiap orang.

Guru, sebagai salah satu agen sosialisasi pada anak, telah mengajarkan mengenai ekspresi emosi di sekolah. Anak-anak seharusnya telah memiliki pengetahuan mengenai emosi dan ekspresi emosinya. Namun, hasil asesmen menunjukkan hasil yang berbeda. Kondisi tersebut disebabkan pembelajaran emosi yang diberikan kepada anak oleh guru berupa informasi mengenai bentuk ekspresi emosi pada wajah seseorang tanpa ada penjelasan mengenai konteks yang berlangsung dalam munculnya situasi tersebut, sehingga anak kesulitan ketika diberikan stimulus emosi dalam suatu konteks tertentu. Ketika anak telah menghadapi situasi tertentu sebelumnya atau berhubungan dengan informasi dengan tugas yang dikerjakan sebelumnya, maka level keberhasilan performa yang dimunculkan akan lebih tinggi daripada ketika konteks yang diberikan tidak dikenali anak, sehingga anak dapat berfungsi secara optimal hanya ketika lingkungannya mendukung secara maksimal terhadap perkembangan anak (Bjorklund, Mulr-Broaddus, \& Schneider, 1990).

Orang tua memiliki peran yang lebih penting dalam mensosialisasikan mengenai pemahaman emosi terhadap anak. Orang tua yang mendiskusikan emosi dengan anak-anaknya berhubungan dengan perkembangan awal 'prosociality', terutama ketika orang tua membantu anaknya menyadari, merenungkan, dan memahami alasan emosi yang dimunculkan orang lain (Brownell, Svetlova, Anderson, Nichols, \& Drummond, 2012). Anak yang memiliki pemahaman emosi pada usia tiga tahun menunjukkan hubungan yang signifikan dengan perilaku prososial pada usia empat tahun (Ensor, Spencer, \& Hughes, 2010). Orang tua yang mendorong anaknya untuk berpartisipasi dalam pengambilan perspektif, baik kognitif maupun afektif, dapat meningkatkan kesiapan dan kemampuan anak untuk berperilaku prososial (Brownell, Svetlova, Anderson, Nichols, \& Drummond, 2012; Farrant, Devine, Maybery, \& Fletcher, 2011).

Dalam menjelaskan mengenai emosi yang dirasakan orang lain, anak-anak menggunakan perilaku yang terobservasi, seperti menangis dan tertawa, bukan menggunakan nama emosinya, yaitu senang dan sedih. Deskripsi konkrit merupakan salah satu karakteristik perkembangan anak awal (Santrock, 2011). Anak prasekolah seringkali mendeskripsikan dirinya dan orang lain dengan 
menggunakan istilah konkrit (Santrock, 2011). Menangis dan tersenyum merupakan perilakukonkrit yang terobservasi oleh anak, sedangkan, senang dan sedih merupakan konsep abstrak yang pada anak prasekolah masih sulit untuk dilaku-kan. Kondisi tersebut dikuatkan dengan lingkung-an di sekolah dan di rumah yang mendukung anak menggunakan istilah konkrit dalam menjelaskan emosi. Santrock (2011) mengatakan bahwa dalam keterampilan kompetensi emosional penggunaan istilah kosakata emosi dipengaruhi oleh kondisi sosial dan budayanya. Meskipun demikian, anak-anak sudah memahami bahwa menangis terasosiasikan dengan situasi tidak menguntungkan dan memunculkan emosi negatif, sehingga mereka dapat memprediksikan respons perilaku prososial apa yang perlu dilakukan.

\section{Kesimpulan}

Kemampuan pengambilan perspektif, yang merupakan salah satu kemampuan dasar agar mampu berperilaku prososial, belum seluruhnya berkembang dengan optimal pada anak. Dari ketiga aspek pengambilan perspektif yang memengaruhi pemahaman anak mengenai situasi yang dihadapi orang lain, sebagian besar anak masih kesulitan dalam melakukan kemampuan pengambilan perspektif afektif, terutama dalam menilai perasaan orang lain dalam konteksnya. Sedangkan hampir seluruh anak telah mampu melakukan pengambilan perspektif perseptual. Untuk aspek pengambilan perspektif kognitif sebagian besar anak sudah mampu menyimpulkan situasi yang dihadapi oleh orang lain terutama ketika sinyal lingkungannya sederhana dan konkrit. Namun, ketika sinyal lingkungannya lebih kompleks, maka anak akan kesulitan untuk menyimpulkan situasi yang dihadapi orang lain.

\section{Keterbatasan dan Saran}

Dalam penelitian ini, terdapat beberapa data yang hilang karena kondisi situasional saat proses asesmen dilakukan, yaitu kondisi dimana anak-anak yang tidak berpartisipasi dalam penelitian memasuki ruangan penelitian secara tidak terkontrol dan ruangan tempat pelaksanaan asesmen yang kurang memadai, sehingga perlu diperhatikan bahwa kondisi rendahnya pengambilan perspektif, terutama pengambilan perspektif kognitif dan afektif, juga dipengaruhi oleh kondisi saat asesmen yang tidak terkontrol. Oleh karena

Naskah masuk: 9 Agustus 2019

Naskah diterima: 8 Mei 2020 itu, pembaca perlu berhati-hati dalam mengeneralisasikan hasil penelitian ini.

Pada penelitian selanjutnya, disarankan memperkaya kajian teoretis mengenai jenis pengambilan perspektif dalam konteks prososial, yaitu perseptual, kogntif, dan afektif, dari tokoh yang serumpun dengan Eisenberg. Tidak banyak perkembangan mengenai konsep ini, baik dalam publikasi oleh Eisenberg maupun oleh peneliti lainnya, sehingga dalam penelitian ini masih menggunakan konsep dasar dari pengambilan perspektif dalam perilaku prososial (Eisenberg, 1986; Eisenberg \& Mussen, 1989).

\section{Daftar Pustaka}

Adni, A. (2017). Rancangan Intervensi Pengembangan Perilaku Prososial Berbasis Kognitif Dan Empati pada Siswa Sekolah Dasar. Magister Tesis, Universitas Padjajaran, Fakultas Psikologi, Jatinangor.

Alfiyah, S., \& Martani, W. (2015). Validasi Modul Bermain "Aku Sayang Kawan" Untuk Meningkatkan Pengetahuan Perilaku Prososial Pada Anak Usia Dini. Gadjah Mada Journal of Professional Psychology, 120-137. https://doi.org/10.22146/gamajpp.9214

Bjorklund, D. F., Mulr-Broaddus, J. E., \& Schneider, W. (1990). The Role of Knowledge in Development of Strategies. Dalam D. F. Bjorklund (Penyunt.), Children's Strategies Contemporary Views of Cognitive Development (hal. 93-128). Hillsdale: Lawrence Erlbaum Associates, Inc.

Borke, H. (1975). Piaget's Mountains Revsisited: Changes in Egocentric Landscape. Developmental Psychology, XI(2), 240-243. https://doi.org/10.1037/h0076459

Bornstein, M. H., Arterberry, M. E., \& Mash, C. (2011). Perceptual Development. Dalam M. H. Bornstein, \& M. E. Lamb (Penyunt.), Cognitive Development An Advance Textbook (hal. 338-387). New York: Psychology Press.

Brownell, C. A. (2013). Early Development of Prosocial Behavior: Current Perspective. Infancy, XVIII(1), 1-9. https://doi.org/10.1111/infa.12004

Brownell, C. A., Svetlova, M., Anderson, R., Nichols, S. R., \& Drummond, J. (2012). Socialization of Early Prosocial Behavior: Parents' Talk About Emotions is Associated With Sharing and Helping in Toddlers. Infancy, XVII(1), 91-119. https://doi.org/10.1111/j.15327078.2012.00125.x

*Fakultas Psikologi, Universitas Padjajaran, Jl. Raya Bandung Sumedang, Kec. Jatinangor, Sumedang, Jawa Barat. E-mail:arlanda.putri@hotmail.com 
Carlo, G., Knight, G. P., McGinley, M., Goodvin, R., \& Roesch, S. C. (2010). The Developmental Relations between Perspective Taking and Prosocial Behavior: A Meta-Analytic Examination of the Task-Specificity Hypothesis. Dalam B. W. Sokol, U. Müller, J. I. Carpendale, A. R. Young , \& G. Iarocci (Penyunt.), Self- and Social-Regulation Social Interaction and the Development of Social Understanding and Executive Functions (hal. 234-269). Oxford University Press.

doi:https://doi.org/10.1093/acprof:oso/9 780195327694.003.0010

Cigala, A., Mori, A., \& Fangareggi, F. (2014). Learning Others' Point Of View: Perspective Taking and Prosocial Behaviour In Preschoolers. Early Child Development and Care, CLXXXV(8). https://doi.org/10.1080/03004430.2014. 987272

Creswell, J. W. (2014). Research Design Qualitative, Quantitative, and Mixed Methods Approaches (Vol. 4th). California: SAGE Publications, Inc.

Creswell, J. W., \& Creswell, J. D. (2018). Research Design Qualitative, Quantitative, and Mixed Methods Approaches (5th ed.). California: SAGE Publications, Inc.

Decety, J., Meidenbauer, K. L., \& Cowell, J. M. (2018). The development of cognitive empathy and concern in preschool children: a behavioral neuroscience investigation. Developmental

Science, 21(3),

e12570. https://doi.org/10.1111/desc. 12570

Eisenberg, N. (1986). Altruistic Emotion, Cognition, and Behavior. New York: Psychology Press.

Eisenberg, N., \& Mussen, P. H. (1989). The Roots of Prososcial Behavior In Children. Cambridge: Cambridge University Press.

Eisenberg, N., \& Sadovsky, A. (2004). Prosocial Behavior, Development of. Dalam C. D. Spielberger (Penyunt.), Encyclopedia of Applied Psychology (hal. 137-141). Elsevier Academic Press.

Eisenberg, N., Cameron, E., \& Tryon, K. (1984). Prosocial Behavior in the Preschool Years Methodological and Conceptual Issues. Dalam E. Staub, D. Bar-Tal, J. Karylowski, \& J. Reykowski (Penyunt.), Development and Maintenance of Prosocial Behavior Interpersonal Perspectives on Positive Morality. New York: Plenum Press.

Eisenberg, N., Eggum, N. D., \& Giunta, L. D. (2010). Empathy-Related Responding: Associations with Prosocial Behavior, Aggression, and Intergroup Relations.
Social Issues and Policy Review, IV(1), 143180. https://doi.org/10.1111/j.17512409.2010.01020.x

Eisenberg, N., Fabes, R. A., \& Spinrad, T. L. (2006). Prosocial Development. Dalam W. Damon, R. M. Lerner, \& N. Eisenberg (Penyunt.), Handbook of Child Psychology: Social, Emotional, and Personality Development (6th ed., Vol. III, hal. 646-718). New Jersey: John Wiley \& Sons, Inc.

Eisenberg, N., Spinrad, T. L., \& Knafo-Foam, A. (2015). Prosocial Development. Dalam R. M. Lernes, \& M. E. Lamb (Penyunt.), Handbook of Child Psychology and Developmental Science: Socioemotional processes (7th ed., Vol. III, hal. 610-656). New Jersey: John Wiley \& Sons Inc.

Ensor, R., Spencer, D., \& Hughes, C. (2010). 'You Feel Sad?' Emotion Understanding Mediates Effects of Verbal Ability and Mother Child Mutuality on Prosocial Behavior: Finding From 2 Years to 4 Years. Social Development, XX(1), 93-110. https://doi.org/10.1111/j.14679507.2009.00572.x

Farrant, B. M., Devine, T. A., Maybery, M. T., \& Fletcher, J. (2011). Empathy, Perspective Taking and Prosocial Behavior: The Importance of Parenting Practices. Infant and Child Development, XXI(2), 175-188. https://doi.org/10.1002/icd.740

Himmah, F., \& Rahmanawati, F. Y. (2013). Perilaku Prososial Anak Usia Dini di Sentra Bermain Peran TK Al-Furqan Jember. INSIGHT Jurnal Pemikiran dan Penelitian Psikologi, IX(1).

Hinnant, J. B., \& O'Brien, M. (2007). Cognitive and Emotional Control and Perpective Taking and Their Relations to Empathy in 5-Yearold Children. The Journal of Genetic Psychology: Research and Theory on Human Development, CLXVIII(3), 301-322. https://doi.org/10.3200/GNTP.168.3.301322

Imuta, K., Henry, J. D., Slaughter, V., Selcuk, B., \& Ruffman, T. (2016). Theory of Mind and Prosocial Behavior in Childhood: A MetaAnalytic Review. Developmental Psychology, LII(8), 1192-1205. https://doi.org/10.1037/dev0000140

Kohler, R. (2008). Jean Piaget. London: Bloombsbury Academic.

Matondang, E. S. (2016). Perilaku Prososial (Prosocial Behavior) Anak Usia Dini Dan Pengelolaan Kelas Melalui Pengelompokan Usia Rangkap (Multiage Grouping). EduHumariora: Jurnal Pendidikan Dasar, $\operatorname{VIII}(1), 34-47$. 
Newcombe, N. (1989). The Development of Spatial Perspective Taking. Dalam H. W. Reese (Penyunt.), Advances in Child Development and Behavior (Vol. XXII, hal.

Longitudinal Study. Social Development, XV(4), 612-627.https://doi.org/10.1111/j.14679507.2006.00360.x

Paulus, M. (2014). The Emergence of Prosocial Behavior: Why Do Infants and Toodlers Help, Comfort, and Share? Child Development Perspective, VIII(2), 77-81. https://doi.org/10.1111/cdep.12066

Piaget, J. (1965). The Moral Judgment of the Child.(Translated by Marjorie Gabain). Routledge \& K. Paul $(1965,1932)$.

Ristic, J., \& Enns, J. T. (2015). Attentional Development. Dalam R. M. Lerner (Penyunt.), Handbook OF Child Psychology And Developmental Science - Cognitive Processes (7th ed., Vol. II, hal. 158-202). New Jersey: John Wiley \& Son, Inc.

Santrock, J. W. (2011). Child Development (13th ed.). New York: McGraw-Hill.
203-247). Elsevier Inc. doi:10.1016/S0065-2407(08)60415-2

Ostrow , J. M., Gentile, D. A., \& Crick, N. R. (2006). Media Exposure, Aggression and Prososcial Behavior During Early Childhood: A

Sierksma, J., Thijs, J., Verkuyten, M., \& Komter, A. (2014). Children's Reasoning About the Refusal of Help: The Role of Need, Costs, and, Social Perspective Taking. Child Development, LXXXV(3), 1134-1149. https://doi.org/10.1111/cdev.12195

Susanti, Siswati, \& Astuti, T. P. (2013). Perilaku Prososial: Studi Kasus Pada Anak Prasekolah. Jurnal Empati, Fakultas Psikologi UNDIP, II(4). Diambil kembali dari http://ejournals1.undip.ac.id/index.php/empati

Theresia, A. (2013). Rancangan Intervensi Untuk Meningkatkan Kemampuan Prososial Melalui Kemampuan Sosiokognitif Anak Usia 6 Tahun. Magister Tesis, Universitas Padjajaran, Fakultas Psikologi, Bandung 


\section{LAMPIRAN A}

Tabel 1. Data Pengambilan Perspektif Kognitif

\begin{tabular}{|c|c|}
\hline Asesmen & Respon Partisipan \\
\hline Kartu bergambar 1 & $\begin{array}{l}\text { Respons populer yang dikemukakan. } \\
\text { "bukunya jatuh karena kebanyakan (Subjek 6)" } \\
\text { "kesulitan membawa buku banyak sehingga jatuh (Subjek 15)" } \\
\text { "bukunya jatuh karena keberatan (Subjek 19)” } \\
\text { Beberapa partisipan mengemukakan respons prososial sebagai berikut. } \\
\text { "membereskan bukunya (Subjek 5)" } \\
\text { "membantu Andi (Subjek 7)" } \\
\text { "membereskan bukunya dengan cara diambilin satu-satu (Subjek } \\
\text { 16)" } \\
\text { "bukunya ditutup-tutupin biar tidak ditiup angin, terus diberesin } \\
\text { (Subjek 17)" } \\
\text { Beberapa partisipan tidak memberikan respons prososial. } \\
\text { "menggunting bukunya, terus ditaruh ke lemari (Subjek 1)” } \\
\text { "tidak tahu (Subjek 18)" }\end{array}$ \\
\hline Kartu bergambar 2 & $\begin{array}{l}\text { Respons yang dikemukakan oleh partisipan paling banyak masuk dalam } \\
\text { tema Ani terjatuh. Berikut ini contoh respon populer yang muncul. } \\
\text { "Ani jatuh dan kesakitan (Subjek 1)" } \\
\text { "Ani jatuh karena kejungkel (Subjek 8)" } \\
\text { "Ani jatuh karena tali (Subjek 11)" } \\
\text { "Ani tidak mau main dengan teman lainnya (Subjek 15)" } \\
\text { Respons perilaku prososial yang dimunculkan oleh mayoritas partisipan } \\
\text { masuk dalam tema memberikan obat dan respons selanjutnya adalah } \\
\text { membantu berdiri atau duduk dan mengajak bermain kembali. Berikut ini } \\
\text { contoh respon yang dikemukakan. } \\
\text { "dikasih obat Aninya (Subjek 16)" } \\
\text { "dibangunin Aninya lalu dibawa kerumah sakit (Subjek 25)" } \\
\text { "mengajak Ani bermain tapi jangan yang jatuh-jatuhan biar Ani } \\
\text { senang (Subjek 7)" }\end{array}$ \\
\hline Kartu bergambar 3 & $\begin{array}{l}\text { Respons yang paling banyak muncul adalah Tina (tokoh yang membawa } \\
\text { makanan) membawa makanan dan Nana (tokoh yang tidak membawa } \\
\text { makanan) hanyak membawa minum, seperti respon berikut ini. } \\
\text { "Tina yang membawa makanan apel, susu, air minum, sama permen, } \\
\text { sama nasi. Dan ada tokoh Nana yang tidak bawa makanan, cuma } \\
\text { bawa air minum (Subjek 6)" } \\
\text { "Tina yang membawa makanan apel, susu, makanan, sama permen } \\
\text { lolipop. Dan ada Nana yang tidak membawa makanan (Subjek 7)" } \\
\text { Respons prososial yang dimunculkan oleh partisipan adalah berbagi } \\
\text { makanan dengan tokoh Nana. } \\
\text { "kalau membawa makanan, akan memberikan makanannya (Subjek } \\
\text { 13)" } \\
\text { "memberikan makanannya karena Nana kelaparan (Subjek 16)" } \\
\text { "dikasih makanannya karena temannya baik (Subjek 22)" } \\
\text { Ada } 2 \text { partisipan yang mengatakan tidak mau berbagi makanannya, seperti } \\
\text { berikut. } \\
\text { "tidak mau memberikan makanannya karena tidak boleh sama } \\
\text { mamanya, takut (subjek) kelaparan (Subjek 23)" } \\
\text { "tidak mau kasih makanan karena Tina jahat (Subjek 25)" }\end{array}$ \\
\hline
\end{tabular}




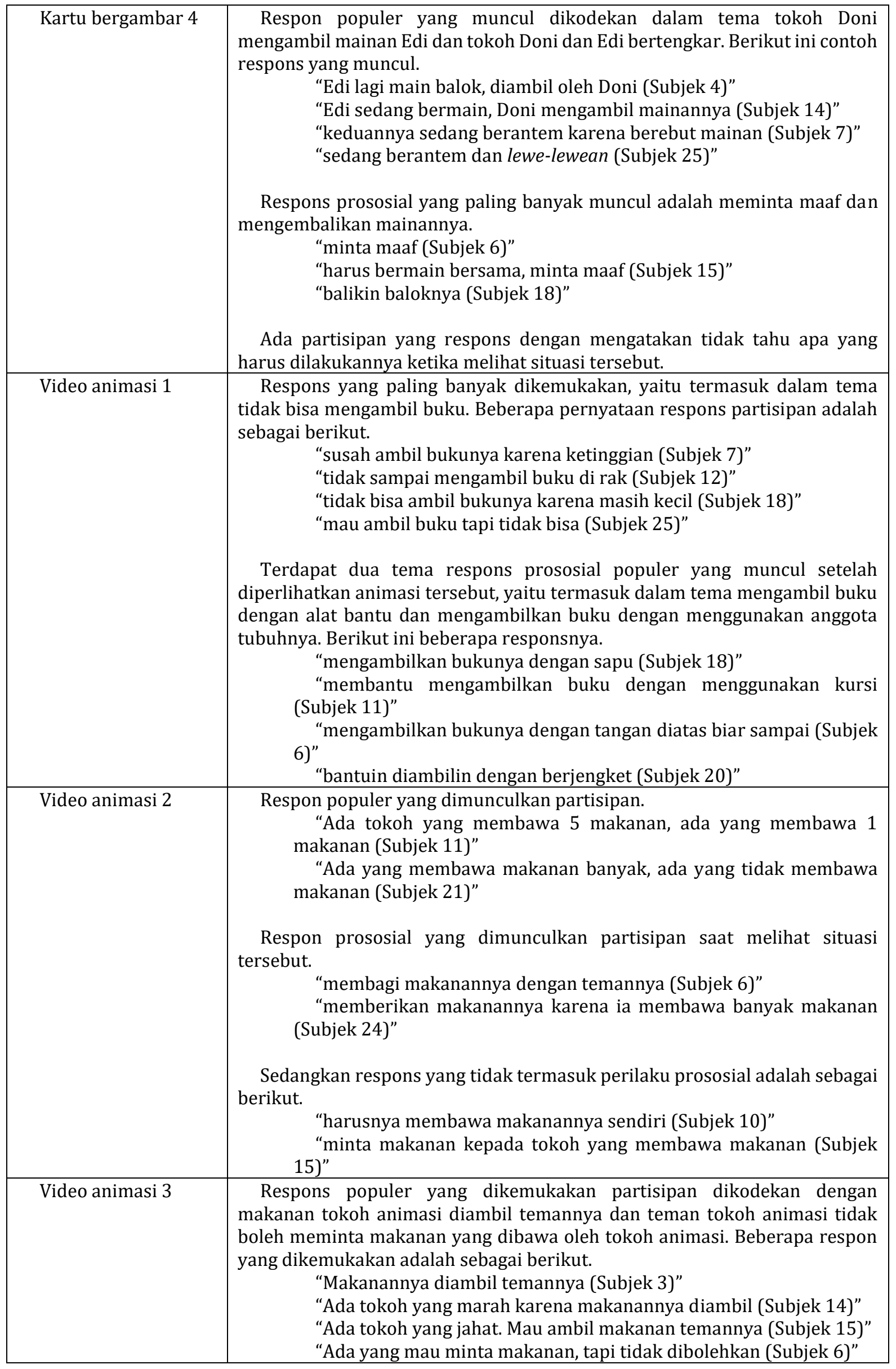




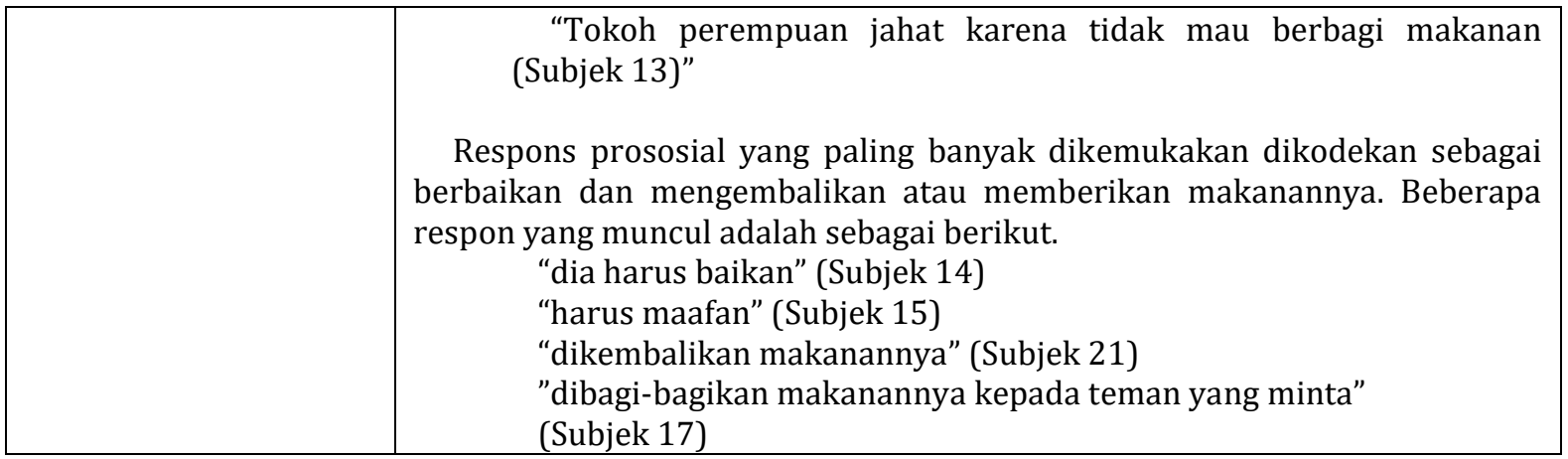

Tabel 2. Data Pengambilan Perspektif Kognitif

\begin{tabular}{|c|c|}
\hline Asesmen & Respon Partisipan \\
\hline Kartu bergambar 1 & $\begin{array}{l}\text { Kebanyakan responden memilih menggunakan kartu bantu ekpresi wajah } \\
\text { untuk mengemukakan perasaan yang dirasakan tokoh. Berikut ini beberapa } \\
\text { respons yang diberikan partisipan. } \\
\text { "S memilih emoticon sedih karena bukunya jatuh (Subjek 16)" } \\
\text { "S memilih emoticon sedih karena bentuk mulutnya mirip (Subjek } \\
\text { 13)" } \\
\text { "S memilih emoticon sedih karena mukanya mirip dengan tokoh } \\
\text { (Subjek 18)" }\end{array}$ \\
\hline Kartu bergambar 2 & $\begin{array}{l}\text { Mayoritas partisipan memilih kartu ekspesi wajah sedih untuk } \\
\text { menerangkan perasaan tokoh Ani dalam stimulus yang diberikan. Terdapat } \\
\text { juga partisipan mengatakan secara verbal bahwa tokoh Ani menangis. Berikut } \\
\text { ini beberapa respon partisipan yang diberikan. } \\
\text { "Memilih emoticon sedih karena mulutnya sama (Subjek 16)" } \\
\text { "Menangis (S tidak dapat menjelaskan alasannya) (Subjek 13)" } \\
\text { "Dianya cengeng (Subjek 5)" } \\
\text { "Menangis karena keluar air mata (Subjek 25)" } \\
\text { Terdapat partisipan yang terdiam dan tidak menjawab pertanyaan yang } \\
\text { diajukan dan ada partisipan yang menjawab pertanyaannya secara tidak } \\
\text { tepat, seperti berikut. } \\
\text { "Ani sedang duduk (Subjek 12)" } \\
\text { "Ani harusnya tidak boleh nangis (Subjek 17)" }\end{array}$ \\
\hline Kartu bergambar 3 & $\begin{array}{l}\text { Respon emosi populer yang dikemukakan partisipan adalah mengatakan } \\
\text { bahwa tokoh Nana (yang tidak membawa makanan) sedang sedih, menangis, } \\
\text { dan memilih kartu ekspresi wajah sedih tanpa dapat menjelaskan secara } \\
\text { verbal. Respons-respons yang muncul sebagai berikut. } \\
\text { "S memilih emoticon sedih karena Nana tidak dibantu oleh Tina } \\
\text { (Subjek 13)" } \\
\text { "S memilih emoticon sedih karena bentuk mulutnya sama (Subjek } \\
\text { 10)" } \\
\text { "Sedih karena tidak membawa makanan (Subjek 1)" } \\
\text { "Sedih karena hanya membawa air putih (Subjek 4)" } \\
\text { Terdapat partisipan yang tidak menjawab dan seorang partisipan } \\
\text { menjawab secara tidak tepat dengan menjawab sebagai berikut. } \\
\text { "Beli aja sendiri (Subjek 10)" }\end{array}$ \\
\hline Kartu bergambar 4 & $\begin{array}{l}\text { Respon populer yang dikemukakan partisipan termasuk dalam tema } \\
\text { bahwa tokoh Edi dalam kartu sedang marah. Beberapa jawaban partisipan } \\
\text { adalah sebagai berikut. } \\
\text { "Edi marah karena sebal (Subjek 1)" } \\
\text { "Marah terus sedih (Subjek 8)" } \\
\text { "Ininya marah (Subjek 25)" }\end{array}$ \\
\hline Video animasi 1 & $\begin{array}{l}\text { Respons populer partisipan mengenai perasaan tokoh animasi adalah } \\
\text { dengan memilih kartu ekspresi wajah sedih, menjawab bahwa perasaan }\end{array}$ \\
\hline
\end{tabular}




\begin{tabular}{|c|c|}
\hline & $\begin{array}{l}\text { tokoh sedang sedih, dan mengatakan bahwa tokoh animasi menangis. } \\
\text { Beberapa contoh respon yang muncul adalah sebagai berikut. } \\
\text { "Perasaannya susah, lalu memilih emoticon sedih (memerlukan } \\
\text { waktu lama untuk memilih) (Subjek 10)" } \\
\text { "Memilih emoticon sedih karena tidak bisa ambil buku (Subjek 20)" } \\
\text { "S memilih emoticon sedih karena memiliki wajah yang sama } \\
\text { dengan tokoh (Subjek 14)" } \\
\text { "Sedih karena tidak bisa ambil buku (Subjek 17)" } \\
\text { Terdapat partisipan yang menjawab pertanyaan dengan tidak tepat dan } \\
\text { terdiam tidak dapat menjawab pertanyaannya. Berikut respons yang muncul. } \\
\text { "Sedang melompat, (ketika diminta memilih emoticon) tidak ada } \\
\text { yang mirip (Subjek 24)" } \\
\text { "Mau minta tolong dibantuin sama ibu guru (Subjek 6)" }\end{array}$ \\
\hline Video animasi 2 & $\begin{array}{l}\text { Ketika melihat tokoh dalam animasi yang tidak membawa makanan, } \\
\text { mayoritas partisipan mengatakan bahwa dia sedih. Beberapa partisipan } \\
\text { mengatakan tokoh sedang cemberut, menangis, dan memilih kartu bantu } \\
\text { ekspresi wajah sedih tan[a dapat menjelaskannya. Selain itu, ada yang tidak } \\
\text { menjawab pertanyaan pada situasi ini. Beberapa hasil yang muncul adalah } \\
\text { sebagai berikut. } \\
\text { "Sedih karena dia tidak bawa makanan (Subjek 1)" } \\
\text { "Cemberut karena tidak membawa makanan (Subjek 20)" } \\
\text { "Dia menangis (Subjek 9)" }\end{array}$ \\
\hline Video animasi 3 & $\begin{array}{l}\text { Respon populer partisipan adalah bahwa tokoh dalam animasi sedang } \\
\text { marah. } 2 \text { partisipan mengatakan sedang menangis, } 1 \text { partisipan mengatakan } \\
\text { sedih dan } 1 \text { partisipan memilih kartu bantuk ekspresi wajah sedih. Berikut ini } \\
\text { beberapa respons yang diberikan. } \\
\text { "Dia marah karena makanannya diambil (Subjek 20)" } \\
\text { "Dia menangis (Subjek 23)" }\end{array}$ \\
\hline
\end{tabular}

